Izabela Tabak

Krystyna Mikiel-Kostyra

Zakład Ochrony i Promocji Zdrowia Dzieci i Młodzieży, Instytut Matki i Dziecka

\title{
Karmienie piersią we wczesnym dzieciństwie, sprawowanie funkcji rodzicielskich w okresie wczesnej adolescencji a masa ciała 13-latków - analiza zależności
}

\section{Wstęp}

Znaczenie karmienia piersią jako czynnika korzystnie wpływającego na różne aspekty zdrowia dziecka, a także matki, łącznie z odległymi pozytywnymi skutkami w dalszym życiu, zostało dobrze udokumentowane badaniami naukowymi (Ip i in., 2007; Mikiel-Kostyra, 2000, 2003; Stuebe, 2009). W licznych publikacjach, jakie ukazały się w ostatnich latach, przedstawiane są wyniki badań dotyczące ochronnego wpływu karmienia piersią w odniesieniu do wystapienia chorób o podłożu immunologicznym oraz ryzyka zaburzeń metabolicznych i nowotworów u dzieci oraz ich matek. Obecnie w kontekście zagrożenia epidemiologicznego nadwagą i otyłością coraz większe zainteresowanie budzi wpływ różnych aspektów wczesnego dzieciństwa na masę ciała starszych dzieci, młodzieży, a także dorosłych. Wyniki badań dotyczących wpływu karmienia piersią niemowląt na masę ciała dzieci w późniejszym okresie życia nie są jednak jednoznaczne (Mon as ta i in., 2010). Prawdopodobnie karmienie piersią nieznacznie obniża ryzyko nadwagi i otyłości, choć mechanizmy patofizjologiczne tej zależności nie są do końca jasne (B artok, Ventura, 2009). Próby wyjaśnienia tych powiązań skupiają się $\mathrm{m}$. in. wokół wpływu leptyny i greliny, zawartych $\mathrm{w}$ mleku matki, na regulację równowagi energetycznej w późniejszym życiu (S a vi n o i in., 2009). Wskazuje się również, że karmienie piersią może sprzyjać utrzymywaniu prawidłowej masy ciała, odgrywając znaczącą rolę w kształtowaniu mechanizmu samoregulacji (B a r tok, Ventura, 2009).

Obecnie badania koncentrują się na poszukiwaniu związków między sposobem żywienia niemowląt, sprawowania funkcji rodzicielskich i wczesnego kształtowania nawyków żywieniowych dzieci a zachowaniami zdrowotnymi i masą ciała w dalszych latach życia (S a vage i in., 2007). Wiele badań wskazuje też na rodzinne determinanty masy ciała, w tym genetyczne oraz związane ze stylem rodzicielskim (B e rg e, 2009). Jako hipotezę rozpatruje się 
możliwość odmiennych zachowań matek, które karmiły piersią oraz karmionych piersią dzieci, w porównaniu z karmiącymi i karmionymi sztucznie (M o n a s ta $\mathrm{i}$ in., 2010). Biorąc jednak pod uwage problemy etyczne związane z prowadzeniem randomizowanych badań eksperymentalnych dotyczących karmienia piersia, wszelkie dane na ten temat pochodzą jedynie $\mathrm{z}$ badań obserwacyjnych i nie dają jasnego obrazu zależności.

Zagadnienie wpływu karmienia piersią na pełnienie funkcji rodzicielskich jest zwykle rozważane w kontekście opieki okołoporodowej i więzi emocjonalnej matki z dzieckiem (K ennel, Klaus, 1998). Interesujące więc było sprawdzenie zależności pomiędzy karmieniem piersią we wczesnym dzieciństwie a praktykami rodzicielskimi i masą ciała dzieci w wieku 13 lat.

\section{Cel pracy}

Celem analizy było ustalenie zależności między czasem trwania karmienia piersią (wyłącznego i utrzymania karmienia) a sposobem sprawowania przez matki funkcji rodzicielskich nad dziećmi oraz masą ciała trzynastolatków.

\section{Material i metody}

\subsection{Osoby badane i procedura}

Badaną grupe stanowiła prospektywna kohorta dzieci włączona do obserwacji $\mathrm{w}$ okresie noworodkowym po porodzie $\mathrm{w}$ szpitalu, poddana badaniu ankietowemu matek w wieku 3 lat, a następnie przebadana w wieku 13 lat. W I etapie badania (w 1995 r.) posłużono się kwestionariuszem wypełnianym przez personel medyczny szpitala dla każdego noworodka urodzonego w Polsce od 1 do 10 stycznia. Zgromadzono zbiór danych o 11937 noworodkach. W II etapie (w 1998 r.) z wyjściowej grupy wybrano podzbiór noworodków urodzonych o czasie z masą ciała co najmniej $2500 \mathrm{~g}$, karmionych piersią, bez chorób przewlekłych $(N=9612)$ i wylosowano 20-procentową próbę $(N=1923)$ objętą drugą fazą badań. Do matek tych dzieci (w wieku 3 lat) drogą pocztową wysłano ankietę zawierającą pytania dotyczące $\mathrm{m}$. in. sytuacji rodzinnej w pierwszym roku życia dziecka. Do analiz zakwalifikowano 1250 ankiet. W III etapie (w 2008 r.) ustalono aktualne adresy zamieszkania 1177 rodzin dzieci z grupy badanych trzylatków, do których wysłano ankiety drogą pocztową. Łącznie otrzymano zwrot 638 ankiet (M ik i e l-K o sty ra, Oblac ińs ka (red.), 2010). 
Badania we wszystkich trzech etapach przeprowadzono metodą sondażu diagnostycznego $\mathrm{z}$ wykorzystaniem techniki ankiety. W trosce o jasność prezentowanych w pracy wyników i spójność prowadzonych analiz zdecydowano się na wykluczenie $\mathrm{z}$ nich rodzin, $\mathrm{w}$ których kwestionariusze zawierały znaczące braki danych lub które wypełniali ojcowie bądź inni opiekunowie (35 osób) oraz tych, w których nastolatkowie mieli niedobór masy ciała (18 uczestników). Ze względu na małą liczebność obu podgrup, nie zdecydowano się na prowadzenie w nich osobnych analiz. Jednocześnie, mając na uwadze specyfikę nastolatków $\mathrm{z}$ niską masą ciała (potencjalnie zwiększone ryzyko zaburzeń somatycznych lub psychicznych), uznano za słuszne niewłączanie ich do grupy osób z prawidłową masą ciała. Dlatego też analizy prezentowane w tej pracy prowadzono wyłącznie wśród matek i nastolatków z prawidłową lub nadmierną masą ciała (531 rodzin). Osoby mieszkające w mieście stanowiły $49 \%$ badanych, a mieszkające na wsi $-51 \%$. Dziewczęta i chłopcy stanowili po $50 \%$ badanej młodzieży.

\subsection{Narzędzia badawcze}

Narzędziem badawczym w I etapie (styczeń 1995) były ankiety zawierające informacje o porodzie i postępowaniu $\mathrm{z}$ noworodkiem podczas pobytu w szpitalu. W kwestionariuszu zawarto szczegółowe informacje o żywieniu noworod$\mathrm{ka}, \mathrm{w}$ tym $\mathrm{m}$. in. dotyczące przebiegu karmienia piersią (kiedy odbyło się pierwsze karmienie z piersi, czy dziecko było dokarmiane, względnie dopajane, i w jaki sposób). Ankiety wypełniane były przez personel szpitala.

Narzędzie badawcze w II etapie (styczeń 1998) stanowiły ankiety zawierające m. in. pytania o sposób żywienia dziecka, ze szczególnym uwzględnieniem okresu i przebiegu karmienia piersią. Definicje sposobu żywienia niemowląt przyjęto zgodnie z definicjami opracowanymi przez Światową Organizację Zdrowia (Indicators..., 1991).

W pracy wykorzystano odpowiedzi na następujące pytania:

1. Do jakiego wieku karmiła Pani dziecko tylko piersią? / to znaczy nie otrzymywało innych pokarmów ani napojów poza mlekiem / (podać, ile dziecko miało miesięcy); przez określenie ,ile dziecko miało miesięcy” rozumiano ukończone miesiące życia dziecka; jeśli dziecko miało poniżej 1 miesiąca, matki podawały wiek w tygodniach ( $\mathrm{w}$ analizach traktowany jako „0"). Odpowiedzi świadczące o tym, że dziecko nigdy nie było karmione wyłącznie piersią, w pracy oznaczono jako ,nigdy”.

2. W jakim wieku dziecka zakończyła Pani w ogóle karmienie piersią / przystawianie do piersi / (podać, ile dziecko miało miesięcy).

Narzędzia badawcze w III etapie składały się z 3 kwestionariuszy ankietowych, w tym: ankiety dla dziecka 13-letniego, ankiety dla rodziców/opiekunów 
oraz formularza pomiarów z listem do pielęgniarki szkolnej z prośbą o zważenie i zmierzenie dziecka. Ankiety dla dzieci i rodziców zawierały m. in. skalę APQ-9 (skróconą wersję Alabama Parenting Questionnaire), analizowaną w tej pracy (Elgar i in., 2007). Skala ta w wersji dla dzieci i rodziców pozwala na przeprowadzenie badań postępowania rodziców w 3 podskalach, uwzględniających następujące elementy: „Wzmacnianie” (positive parenting), „dyscyplinę” (inconsistent discipline) oraz „kontrolę” (poor supervision). Skala składa się z 9 pytań (po 3 pytania w każdej podskali) z kategoriami odpowiedzi: „nigdy”, „prawie nigdy”, „czasami”, „często”, „zawsze”. Podskala „wzmacnianie” dotyczy stosowania przez rodzica pozytywnych bodźców w stosunku do dziecka („Moja mama chwali mnie, gdy zrobię coś dobrze; daje mi odczuć, że dobrze sobie z czymś radzę; nagradza mnie za dobre zachowanie”), podskala „dyscyplina" umożliwia ocenę niekonsekwentnego działania w karaniu dziecka („Moja mama grozi mi, że mnie ukarze, a potem tego nie robi; przekonuję ją, żeby mnie nie karała, gdy zrobię coś złego; zwalnia mnie z ustalonej kary wcześniej, niż zapowiedziała”), podskala „kontrola” pozwala na ujawnienie braku kontroli rodzica nad tym, co robi dziecko, z kim przebywa („Wieczorami pozostaję poza domem dłużej niż mi na to mama pozwala”; „Nie zostawiam wiadomości i nie mówię jej, dokąd idę”; „Spędzam czas poza domem ze znajomymi, których nie zna"). Odpowiedzi punktowane są odpowiednio od 1 do 5 pkt, więc w każdej podskali można uzyskać od 3 do 15 pkt. Wyższa punktacja uzyskana w podskali „Wzmacnianie” świadczy o bardziej pozytywnej ocenie postępowania rodziców. W zakresie podskal „dyscyplina” i „kontrola”, wysokie wyniki świadczą o niekorzystnych zjawiskach zachodzących w rodzinie.

Pytania zadawano zarówno rodzicom (jako samoocenę własnych praktyk rodzicielskich), jak i dzieciom (w odniesieniu do oceny funkcji rodzicielskich pełnionych przez matkę i osobno przez ojca). W tej pracy wykorzystano odpowiedzi dzieci dotyczące oceny postępowania matek oraz samoocenę postępowania dokonaną przez matki. Formularz pomiarów wysokości i masy ciała dziecka wypełniany był przez pielęgniarkę szkolną po dokonaniu przez nią wymienionych pomiarów. Na podstawie tych danych obliczono dla każdego dziecka wskaźnik masy ciała BMI. Jako normą referencyjną stanu odżywienia w prowadzonych analizach posłużono się siatkami centylowymi BMI opracowanymi przez Światową Organizację Zdrowia (Indicators..., 2007).

Analiza statystyczna zebranych danych przeprowadzona za pomoca pakietu statystycznego SPSS v. 14 zawierała analizę istotności różnic (test $\chi^{2}$ ), jednoczynnikową analizę wariancji ANOVA oraz oszacowanie wielowymiarowych modeli regresji logistycznej. Zastosowano również dwustopniową analizę skupień, do której włączono dwie zmienne ciąłe: „czas trwania wyłącznego karmienia piersią” i „czas trwania karmienia piersią ogółem” oraz zmienną dychotomiczną podjęcia (lub nie) wyłącznego karmienia piersią. 


\section{Wyniki}

1. Czas trwania karmienia piersią dzieci a postępowanie matek wobec nich w wieku 13 lat. Ponad połowa osób badanych $(62,1 \%)$ w dzieciństwie była karmiona piersią (ogółem) przez okres 0-6 miesięcy, 20\% przez 7-12 miesięcy, a 17,9\% dłużej niż 1 rok. Analizy dotyczące wyłącznego karmienia piersią wykazały, że najliczniejszą grupę stanowiły dzieci karmione w ten sposób przez 0-3 miesiące $(63,9 \%)$. Dzieci karmionych wyłącznie piersią przez co najmniej 4 miesiące było $27 \%$. Wśród badanych znalazło się również 48 dzieci $(9,1 \%)$, które nigdy nie były karmione wyłącznie piersią.

Za pomocą dwustopniowej analizy skupień wyodrębniono 3 skupienia różniące się czasem trwania karmienia piersią (wyłącznego i ogółem) (tab. 1). Skupienie 1. określono jako „dzieci nigdy nie karmione wyłącznie piersią”, skupienie 2. - „dzieci krótko karmione piersią”, skupienie 3. - „dzieci długo karmione piersią".

T a b e la 1

Wyniki analizy skupień - wartości średnie $(M)$, odchylenia standardowe $(S D)$ i mediany $(M d n)$ dla czasu trwania karmienia piersią w każdym skupieniu oraz różnice wartości średnich pomiędzy trzema skupieniami

\begin{tabular}{|c|c|c|c|c|c|c|c|c|c|c|c|}
\hline \multirow{2}{*}{$\begin{array}{l}\text { Karmienie } \\
\text { piersią }\end{array}$} & \multicolumn{3}{|c|}{$\begin{array}{c}\text { Skupienie } 1 \\
N=20\end{array}$} & \multicolumn{3}{|c|}{$\begin{array}{c}\text { Skupienie } 2 . \\
N=309\end{array}$} & \multicolumn{3}{|c|}{$\begin{array}{c}\text { Skupienie } 3 \text {. } \\
N=154\end{array}$} & \multirow[t]{2}{*}{$F$} & \multirow[t]{2}{*}{$p$} \\
\hline & $M$ & $S D$ & $M d n$ & $M$ & $S D$ & $M d n$ & $M$ & $S D$ & $M d n$ & & \\
\hline $\begin{array}{l}\text { Ogólny czas } \\
\text { trwania kar- } \\
\text { mienia piersią }\end{array}$ & 4,85 & 5,7 & 3,0 & 3,59 & 2,7 & 3,0 & 15,88 & 8,3 & 13,0 & 282,7 & $<0,001$ \\
\hline $\begin{array}{l}\text { Czas trwania } \\
\text { wyłącznego } \\
\text { karmienia } \\
\text { piersią }\end{array}$ & 0 & 0 & 0 & 1,64 & 1,1 & 2,0 & 4,92 & 2,0 & 5,0 & 302,7 & $<0,001$ \\
\hline $\begin{array}{l}\text { Podjęcie wy- } \\
\text { łącznego kar- } \\
\text { mienia piersią }\end{array}$ & \multicolumn{3}{|c|}{ nie } & \multicolumn{3}{|c|}{ tak } & \multicolumn{3}{|c|}{ tak } & & \\
\hline $\begin{array}{l}\text { Interpretacja wy- } \\
\text { niku analizy } \\
\text { skupień }\end{array}$ & \multicolumn{3}{|c|}{$\begin{array}{c}\text { dzieci nigdy nie } \\
\text { karmione wylącznie } \\
\text { piersia }\end{array}$} & \multicolumn{3}{|c|}{$\begin{array}{l}\text { dzieci krótko } \\
\text { karmione piersią }\end{array}$} & \multicolumn{3}{|c|}{$\begin{array}{c}\text { dzieci długo karmione } \\
\text { piersią }\end{array}$} & & \\
\hline
\end{tabular}

Źródło: opracowanie własne.

Dzieci długo karmione piersią w wieku 13 lat najbardziej pozytywnie ze wszystkich analizowanych podgrup oceniały konsekwencję stosowanej przez swoje matki dyscypliny oraz sprawowaną przez nie kontrolę (rys. 1). Podobne oceny swojego postępowania wystawiły matki tych dzieci. 


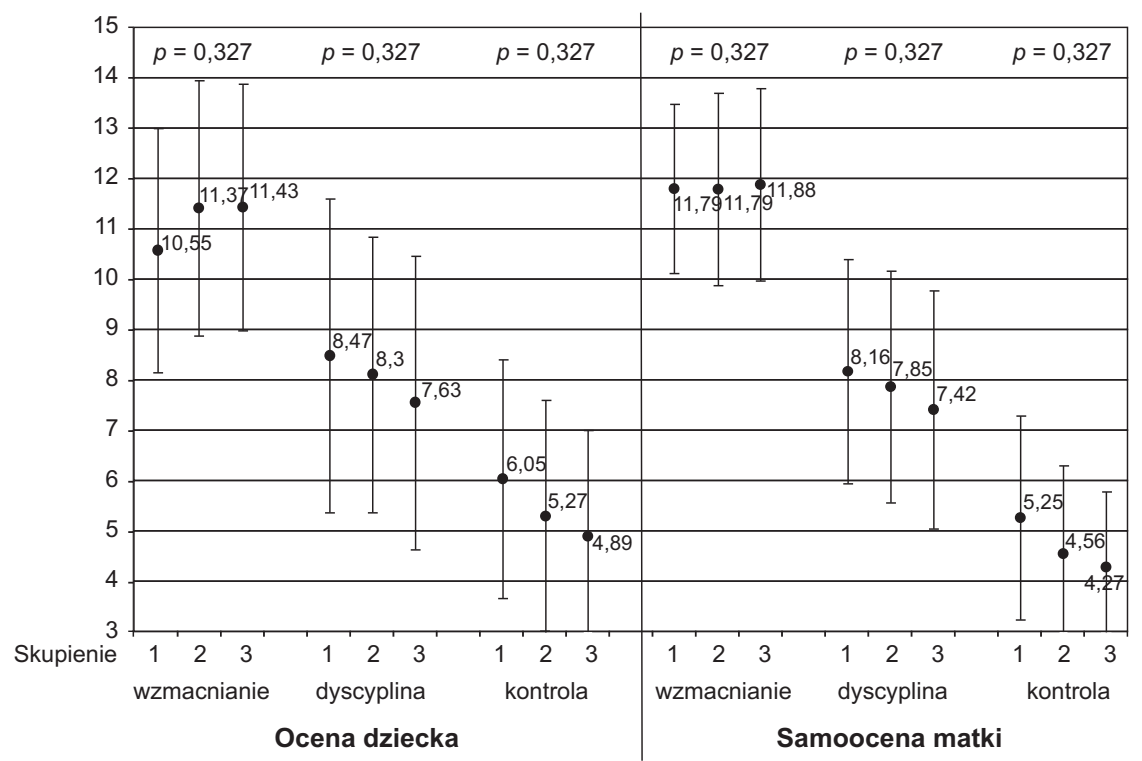

Rys. 1. Wartości średnie z odchyleniem standardowym wyników podskal APQ-9 oraz poziomem istotności różnic pomiędzy skupieniami

Skupienie 1. - dzieci nigdy nie karmione wyłącznie piersią, skupienie 2. - dzieci krótko karmione piersią, skupienie 3. - dzieci długo karmione piersią.

Źródło: opracowanie własne.

2. Czas trwania karmienia piersią dzieci a ich masa ciała w wieku 13 lat. W badanej próbie, ogółem 79,3\% młodzieży miało prawidłową masę ciała (wskaźnik $B M I$ w normie), a 20,7\% nadmiar masy ciała (nadwagę lub otyłość) (tab. 2). Odsetki młodzieży o prawidłowej lub nadmiernej masie ciała nie różniły

Tabela 2

Odsetki młodzieży z prawidłową i nadmierną masą ciała w skupieniach wyróżnionych ze względu na czas trwania karmienia piersią

\begin{tabular}{|l|c|c|c|}
\hline \multirow{2}{*}{ Karmienie piersią } & \multicolumn{2}{|c|}{$B M I$} & \multirow{2}{*}{$p$} \\
\cline { 2 - 3 } & $\begin{array}{c}\text { prawidłowa masa } \\
\text { ciała }\end{array}$ & $\begin{array}{c}\text { nadmiar masy } \\
\text { ciała }\end{array}$ & \multirow{2}{*}{0,608} \\
\cline { 1 - 3 } $\begin{array}{l}\text { Skupienie 1. (dzieci nigdy nie karmione wyłącznie } \\
\text { piersią) }\end{array}$ & 75,0 & 25,0 & \\
\hline Skupienie 2. (dzieci krótko karmione piersią) & 79,3 & 20,7 & \\
\hline Skupienie 3.(dzieci długo karmione piersią) & 82,5 & 17,5 & \\
\hline Ogółem & $\mathbf{7 9 , 3}$ & $\mathbf{2 0 , 7}$ & \\
\hline
\end{tabular}

Źr ó d ło: opracowanie własne. 
się istotnie statystycznie pomiędzy podgrupami wyróżnionymi ze względu na długość okresu karmienia piersią (wyłącznego i ogółem). Nie wykazano również istotnych statystycznie różnic pomiędzy skupieniami, choć kierunek zależności wskazywał na to, że wraz z wydłużeniem okresu karmienia piersią odsetek młodzieży z nadwagą i otyłością zmniejszał się.

3. Postępowanie matek a masa ciała 13-latków. Przeprowadzono analizy różnic częstości występowania nadmiaru masy ciała u dzieci w zależności od postępowania ich matek (test $\chi^{2}$ ) oraz wielowymiarową analizę regresji logistycznej dla oszacowania ryzyka występowania nadmiaru masy ciała u dzieci, których matki rzadko stosowały pozytywne wzmocnienia (chwalenie, nagradzanie), często zaś niekonsekwentną dyscyplinę oraz niedostateczną kontrolę (tab. 3).

T a b e la 3

Postępowanie matek a częstość występowania nadmiaru i prawidłowej masy ciała u młodzieży (\% odpowiedzi, istotność różnic mierzona testem $\chi^{2}$ oraz wyniki analizy regresji logistycznej dla ryzyka wystąpienia nadmiaru masy ciała w przypadku nieprawidłowości w postępowaniu matek)

\begin{tabular}{|c|c|c|c|c|c|c|}
\hline \multicolumn{7}{|c|}{ Ocena dziecka } \\
\hline \multicolumn{2}{|c|}{ postępowanie matki } & prawidłowe & nadwaga & $p$ & $\exp (B)$ & $p$ \\
\hline \multirow{2}{*}{ Wzmacnianie } & rzadkie $\quad(3-11 \mathrm{pkt})$ & 77,3 & 22,7 & \multirow{2}{*}{0,312} & \multirow{2}{*}{1,309} & \multirow{2}{*}{0,227} \\
\hline & częste $(12-15 \mathrm{pkt})$ & 80,8 & 19,2 & & & \\
\hline \multirow{2}{*}{ Dyscyplina } & $\begin{array}{l}\text { niekonsekwentna } \\
\qquad(7-15 \text { pkt) }\end{array}$ & 76,8 & 23,2 & \multirow{2}{*}{0,026} & \multirow{2}{*}{1,753} & \multirow{2}{*}{$\mathbf{0 , 0 3 9}$} \\
\hline & $\begin{array}{l}\text { konsekwentna } \\
\qquad(3-6 \text { pkt) }\end{array}$ & 85,4 & 14,6 & & & \\
\hline \multirow{2}{*}{ Kontrola } & słaba $\quad(7-15 \mathrm{pkt})$ & 78,6 & 21,4 & \multirow{2}{*}{0,840} & \multirow{2}{*}{0,937} & \multirow{2}{*}{0,796} \\
\hline & dobra $\quad(3-6 \mathrm{pkt})$ & 79,4 & 20,6 & & & \\
\hline \multicolumn{7}{|c|}{ Samoocena matki } \\
\hline \multicolumn{2}{|c|}{ postępowanie matki } & $\begin{array}{c}\text { prawidłowe } \\
B M I(\%)\end{array}$ & $\begin{array}{c}\text { nadwaga } \\
\text { i otyłość }(\%)\end{array}$ & $p$ & $\exp (B)$ & $p$ \\
\hline \multirow{2}{*}{ Wzmacnianie } & Rzadkie (3-11 pkt) & 82,2 & 17,8 & \multirow{2}{*}{0,183} & \multirow{2}{*}{0,714} & \multirow{2}{*}{0,150} \\
\hline & Częste $(12-15 \mathrm{pkt})$ & 77,4 & 22,6 & & & \\
\hline \multirow{2}{*}{ Dyscyplina } & $\begin{array}{l}\text { niekonsekwentna } \\
\qquad(7-15 \mathrm{pkt})\end{array}$ & 78,2 & 21,8 & \multirow{2}{*}{0,264} & \multirow{2}{*}{1,487} & \multirow{2}{*}{0,132} \\
\hline & $\begin{array}{l}\text { konsekwentna } \\
\qquad(3-6 \mathrm{pkt})\end{array}$ & 82,6 & 17,4 & & & \\
\hline \multirow{2}{*}{ Kontrola } & $(7-15 \mathrm{pkt})$ & 80,7 & 19,3 & \multirow{2}{*}{0,678} & \multirow{2}{*}{0,738} & \multirow{2}{*}{0,345} \\
\hline & $(3-6 \mathrm{pkt})$ & 78,7 & 21,3 & & & \\
\hline
\end{tabular}

Źr ódło: opracowanie własne. 
Istotne zależności otrzymano $\mathrm{w}$ odniesieniu do konsekwencji dyscypliny stosowanej przez matkę (w ocenie dziecka). Większe odsetki dzieci z nadmiarem masy ciała stwierdzono w grupie dzieci, w których matki stosowały mniej konsekwentną dyscyplinę (23,2\% vs $14,2 \%)$. Ryzyko wystapienia nadmiaru masy ciała u dzieci, wobec których matki stosowały niekonsekwentną dyscyplinę, było prawie dwa razy większe $(\exp (B)=1,75 ; p<0,05)$ niż u pozostałych rówieśników. $\mathrm{W}$ przypadku pozostałych podskal nie wykazano żadnych istotnych statystycznie zależności.

\section{Dyskusja}

Znaczenie karmienia piersią dla kształtowania więzi i relacji między matką a dzieckiem było od dawna najczęściej przedstawianym argumentem za naturalnym karmieniem dzieci (Matthews Grieco, Corsini, 1991). W latach 70. XX w. opublikowano wiele wyników badań, w tym również eksperymentalnych, dotyczących korzystnego wpływu stymulacji dzieci przedwcześnie urodzonych przez dotyk, kołysanie, tulenie, bodźce werbalne i inne formy bliskiego kontaktu na rozwój niemowląt i sprawowanie funkcji opiekuńczych przez rodziców. Podkreślano, że karmienie piersią tworzy naturalną sytuację, w której wszystkie elementy stymulacji dziecka występują samoistnie (K la u s, K e n n e 11, 1982). Nowsze badania wykazały, że kobiety karmiące dzieci piersią dłużej niż osiem tygodni, w porównaniu z karmiącymi krócej, były bardziej zrelaksowane, wykazywały większą tolerancję na monotonię życia codziennego i uzyskiwały wyższe oceny $\mathrm{w}$ skali, w której badano stopień socjalizacji (S jorgen i in., 2000).

Rosnąca aktywizacja zawodowa kobiet sprawiła, że zagadnienia karmienia piersią i zachowań kobiet karmiących były rzadko uwzględniane w badaniach. $\mathrm{W}$ ostatnich latach nie znaleziono publikacji omawiających bezpośrednio zależności miedzy karmieniem piersią a sprawowaniem funkcji rodzicielskich. Pośrednich informacji dostarczają badania zjawisk neurohormonalnych zachodzących podczas laktacji (Bartok, Ventura, 2009; Carter, Altemus, 1997; F r a n c e e sh in i i in., 1989; R u s se 1 i in., 2001). Wykazano, że wydzielane podczas stymulacji matki przez ssące dziecko prolaktyna, oksytocyna i endogenne opioidy wpływają euforyzująco na usposobienie kobiety, zwiększają odporność na stres, wyzwalają funkcje opiekuńcze i zadowolenie z macierzyństwa. Można więc zakładać, że szczególny stan psychiczny karmiących kobiet wpływa na sposób opiekowania się dzieckiem, poczucie bezpieczeństwa i funkcjonowanie rodziny.

Nieliczne doniesienia $\mathrm{z}$ tego zakresu publikowane w ostatnim okresie dotyczą kontroli żywienia dziecka i uwzględniają tylko bardzo krótki, ograniczający się do pierwszego roku życia, okres obserwacji. Im dłużej matki karmiły piersią, 
tym mniej restrykcyjnie kontrolowały żywienie dziecka w wieku 12 miesięcy. Matki, które karmiły wyłącznie piersią dzieci 6-miesięczne w porównaniu z tymi, które nigdy nie karmiły, zachowywały się trzykrotnie mniej restrykcyjnie (T a veras in., 2004). Interakcja matek z dziećmi podczas posiłków rocznych dzieci była też bardziej pozytywna. Matki, mające doświadczenie karmienia piersią, wywierały na dziecko mniejszą presję, aby jadło, i były bardziej otwarte na potrzeby dziecka. Przekładało się to na mniejszą liczbę sytuacji konfliktowych i otwartych konfliktów z dzieckiem podczas spożywania posiłków (F arrow, B lis sett, 2006).

\subsection{Czas trwania karmienia piersią a postępowanie matek wobec 13-latków}

Przedstawione w naszej pracy wyniki analiz pokazują tzw. efekt dawki. Matki, które dłużej karmiły swoje dzieci piersią, w tym wyłącznie piersią, prezentowały bardziej korzystny i pożądany styl macierzyństwa realizowany wobec swoich 13-letnich dzieci. Matki te stosowały wobec nich dyscyplinę w sposób bardziej konsekwentny, wykazywały też więcej troski o dziecko, przejawiającej się zainteresowaniem tym, co robi ono poza domem. Prawdopodobnie stosunkowo mała liczebność analizowanych grup nie pozwoliła na pełne wykazanie zależności.

Uzyskane zależności można interpretować dwukierunkowo. Z jednej strony można postawić hipotezę, że pomiędzy matkami a dziećmi podczas kilkumiesięcznego okresu karmienia piersią powstaje na tyle silna więź emocjonalna, że zwiększa ona w kolejnych latach życia dziecka prawdopodobieństwo podejmowania przez matkę pożądanych praktyk rodzicielskich, takich jak skuteczny monitoring (kontrola) czy konsekwentna dyscyplina. Należy pamiętać o tym, że jak wskazują badania dotyczące kontroli, realna wiedza rodziców o tym, co robią ich dzieci w czasie wolnym jest zwykle oparta właśnie na więzi i zaufaniu (Ke r r i in., 1999).

Argumentami przemawiającymi za taką interpretacją są wyniki badań wskazujących na to, że bliski kontakt fizyczny między matką a dzieckiem w pierwszych tygodniach życia dziecka zwiększa prawdopodobieństwo ukształtowania się bezpiecznego stylu przywiązania (A n is feld i in., 1990). Sytuacja karmienia jest też w pierwszych miesiącach życia dziecka główną okazją do interakcji matka-dziecko. Dostarcza ona matce sposobności do wykształcenia wrażliwości na sygnały płynące od dziecka i zdolności dopasowywania swoich interwencji do sposobu zachowań dziecka (B o w l by, 2007).

Jednocześnie, wśród zalet karmienia piersią zwykle wymieniane są, poza skutkami fizycznymi, również pozytywne skutki psychologiczne dla dzieci i matek. Dotyczą one m. in. pełnego „cieszenia się macierzyństwem i odczuwania miłości macierzyńskiej”, dzięki poczuciu dobrego wypełniania swoich rodziciel- 
skich obowiązków, nagradzanych przez dziecko uśmiechem czy tuleniem się (S pok, Rothenberg, 2000). Należy jednak pamiętać o tym, że w ciągu kolejnych kilkunastu lat życia na matkę i dziecko oddziałuje bardzo wiele innych czynników, które mogą zakłócać obserwowane zależności.

Drugi sposób interpretacji uzyskanych w badaniu wyników to postawienie hipotezy, że matki, które decydują się na wielomiesięczne karmienie piersią, posiadają określone cechy osobowości - są bardziej konsekwentne, gotowe do poświęceń dla dobra dziecka. Decyzja o kilkumiesięcznym (a niekiedy nawet trzyletnim) utrzymywaniu karmienia dziecka piersią wymaga od rodziców (przede wszystkim matek) pewnych wyrzeczeń (związanych $\mathrm{z}$ odpowiednią dieta, unikaniem używek, koniecznością stałej obecności) i sporej determinacji $\mathrm{w}$ przezwyciężaniu pojawiających się przejściowych trudności w karmieniu piersią (S pok, Rothenberg, 2000). Hipoteza ta, choć wydaje się bardzo prawdopodobna, wymaga jednak weryfikacji empirycznej. Badania, dotyczące jednocześnie czasu trwania karmienia piersią i cech charakteryzujących matki, które karmią lub nie karmią piersią swoich dzieci, pozwoliłyby na wykazanie ewentualnych zależności.

\subsection{Czas trwania karmienia piersią dzieci a ich masa ciala w wieku 13 lat}

Przeprowadzone analizy wskazują na bardzo słabe (nieistotne statystycznie) zależności pomiędzy okresem karmienia piersią niemowlęcia a zaburzeniami w zakresie $B M I$ u nastolatków. Odsetki młodzieży z nadmiarem masy ciała nie różniły się istotnie pomiędzy grupami wyróżnionymi ze względu na długość okresu karmienia piersią. Można było jednak zauważyć pewną tendencję, że wraz z wydłużeniem okresu karmienia piersią odsetek młodzieży z nadwagą i otyłością zmniejszał się. Obserwacja ta jest zgodna z doniesieniami z metaanaliz, łączących wyniki wielu badań z tego zakresu i wskazujących na zgodny kierunek zależności, choć nie zawsze osiaganą istotność statystyczną (P la g e man n, Harder, 2005).

\subsection{Postępowanie matek a masa ciala 13-latków}

Analizy zależności między postępowaniem matki (stosowaniem pozytywnych wzmocnień, dyscypliny i kontroli) a występowaniem nadmiaru masy ciała u młodzieży wskazały, że istotnym predyktorem tego zaburzenia rozwoju jest niekonsekwentnie prowadzona dyscyplina matki. W tym przypadku ryzyko nadwagi i otyłości u młodzieży jest niemal dwukrotnie większe. Wynik ten może wskazywać na zależności pomiędzy konsekwentnie stosowaną dyscypliną, jako elementem szerszego sposobu sprawowania funkcji rodzicielskich, a zachowaniami prozdrowotnymi młodzieży. Jak wskazują badania analizujące 
zależności pomiędzy stylem rodzicielskim a zachowaniami żywieniowymi i aktywnością fizyczną dzieci, styl autorytatywny, charakteryzujący się konsekwencją i jasnym określeniem oczekiwań wobec dziecka w połączeniu z wysokim poziomem ciepła rodzinnego wiąże się ze wzrostem częstości konsumpcji owoców, wzrostem poziomu aktywności fizycznej i spadkiem częstości tzw. zachowań sedenteryjnych (związanych z siedzącym trybem życia) (Gol a n, Crow, 2004).

Prowadzone od kilkudziesięciu lat analizy funkcjonowania rodzin dzieci z nadmiarem masy ciała wskazują również na większą chaotyczność organizacji i postępowania tych rodzin w porównaniu z rodzinami dzieci z prawidłową masą ciała (B r o m b e r g, 1977). Rodziny te ujawniają również inne charakterystyczne cechy, sprzyjające powstawaniu zaburzeń odżywiania, takie jak splątanie (brak wyznaczonych granic dziecko - rodzic), nadopiekuńczość, sztywność (unikanie zmian), unikanie i nierozwiązywanie konfliktów (L o a der, 1985). $\mathrm{W}$ rodzinach dzieci otyłych $\mathrm{w}$ porównaniu $\mathrm{z}$ rodzinami dzieci o prawidłowej masie ciała znacznie częściej występują dysfunkcje i zaburzenia emocjonalne (Konston i in., 1987). Problemy psychologiczne, z którymi zmagają się rodzice otyłych dzieci mogą stać się predyktorami zaburzeń pojawiających się u młodzieży (bezpośrednio bądź poprzez mediatory, do których należy niekonsekwentna dyscyplina) (D e c a lu vè i in., 2006).

\section{Wnioski końcowe}

Wyniki uzyskane w badaniu są bardzo obiecujące. Od wielu lat próbowano wykazać zależności pomiędzy karmieniem piersią dziecka a jego masą ciała w późniejszym życiu, uzyskując niejednoznaczne wyniki (Monasta, 2010; P l a g e man n, Hard er, 2005). Stwierdzano, że karmienie piersią nieznacznie obniża ryzyko nadwagi i otyłości, choć trudno było wyjaśnić mechanizm tej zależności. Przeprowadzone badania moga przyczynić się do lepszego zrozumienia tych relacji.

Traktując okres trwania karmienia dziecka piersią nie jako bezpośredni predyktor, lecz jako czynnik, którego wpływ na masę ciała dzieci jest mediowany lub wzmacniany przez postępowanie rodziców, możemy zrozumieć, dlaczego wyniki różnych badań z tego zakresu są niejednoznaczne, zwłaszcza w odniesieniu do otyłości. Otyłość prosta jest bowiem zaburzeniem, w którym, zgodnie $\mathrm{z}$ wielogenowym charakterem dziedziczenia, decydującą rolę odgrywa wpływ czynników środowiskowych, w tym stylu życia i zachowań zdrowotnych na ujawnienie się fenotypu otyłości (np. pojadanie między posiłkami czy uprawianie aktywności fizycznej) (O b l a c iń s k a, 2009). 


\section{Bibliografia}

A n is fe $1 \mathrm{~d}$ E., C a s per V., N o z y c e M., C u n n ing ha m N. (1990), Does infant carrying promote attachment?, An experimental study of the effect of increased physical contact on the development of attachment, „Child Development”, 61, 1617-1627.

Bartok C. J., Ventura A. K. (2009), Mechanisms underlying the association between breastfeeding and obesity, ,International Journal of Pediatric Obesity”, 4, 196-204.

B e r g e J. (2009), A review of familiar correlates of child and adolescent obesity: What has the $21^{\text {th }}$ century taught us so far?, „International Journal of Adolescent Medicine and Health”, 21 (4), 457-483.

B o w 1 b y J. (2007), Przywiazanie, Wydawnictwo Naukowe PWN, Warszawa.

B ro m b e rg D. (1977), Family dominance patterns and the decision-making process in obese and non-obese families, „Dissertation Abstracts International”, 37, 35-97.

C a rte r C. S., A l t e mu s M. (1997), Integrative functions of lactational hormons in social behaviours and stress management, „Annual New York Academy of Medicine”, 807, 164-174.

De caluvé V. i in. (2006), The association of parental characteristics and psychological problems in obese youngsters, „International Journal of Obesity”, 30, 1766-1774.

E 1 gar F., W a s chbu sch D., Dadds M., Sigvaldas on N. (2007), Development and validation of a short form of the Alabama Parenting Questionnaire, „Journal of Child and Family Studies", 16, 243-259.

F a rrow C., B lis s ett J. (2006), Breastfeeding, maternal feeding practices and mealtime negativity at one year, „Appetite”, 46, 49-56.

France e shin i R., Ve nt u rin i P., C a tald i A. (1989), Plasma beta-endorfin concentration during suckling in lactating woman, „British Journal of Obstetrics and Gynaecology”, 96, 711-713.

G o 1 a n M., C r o w S. (2004), Parents are key players in the prevention and treatment of weightrelated problems, „Nutrition Reviews”, 62 (1), 39-50.

Indicators for assessing breast-feeding practices (1991), World Health Organization, Geneva.

I p S., Chung M., Raman G., Chew P., Magula N., De Vine D., Trikalinos T., $\mathrm{L}$ a u J. (2007), Breastfeeding and maternal and infant healthy outcomes in developed countries, ,Evidence Report/Technology Assessment”, Full Report, 153, 1-181.

K e n n e 11 J. H., K 1 a u s M. H. (1998), Bonding: Recent observation that alter perinatal care, „Pediatric Review”, 19, 4-12.

K e r r M., S t a t t i n H., T r o s t K. (1999), To know you is to trust you: parents' trust is rooted in child disclosure of information, ,Journal of Adolescence”, 22, 737-752.

Kl a u s M. H., Kennell J. H. (1982), Parent-infant bonding, Mosby, St. Luis-TorontoLondon.

Konst on W., U x bridge E., L o a d e r P., Mille r L. (1987), Emotional health of families and their members where a child is obese, „Journal of Psychosomatic Research”, 31 (5), 583-599.

L o a d e r P. (1985), Childhood obesity: the family perspective, „International Journal of Eating Disorders", 4 (2), 211-225.

Mat thews Griec o S. F., C or s in i C. A. (1991), Historical perspectives on breastfeeding, UNICEF, Florence.

Miki el-Kostyra K. (2000), Karmienie piersia jako element cyklu rozrodczego kobiety, „Ginekologia Polska”, 71, 641-647. 
Mikiel-Kostyra K. (2003), Odlegte skutki zdrowotne sposobu żywienia niemowlat, „Medycyna Wieku Rozwojowego”, VII (4), cz. II, 605-615.

M i k i e l-K o s ty r a K., O bla c iń s k a A. (red.) (2010), Czynniki biologiczne, behawioralne i psychospoleczne kształtujace masę ciała (BMI) 13-latków, Instytut Matki i Dziecka, Warszawa.

Monasta L., B atty G. D., Cattane o A., Lutje V., Ronfani L., Van Lenthe F. J., $\mathrm{Br}$ u J. (2010), Early-life determinants of overweight and obesity: a review of systematic reviews, „Obesity Review”, 11 (10), 695-708.

O bla c ińska A. (2009), Otyłość dzieci i młodzieży $w$ Polsce - wyzwanie dla profilaktyki i edukacji zdrowotnej, „Edukacja Biologiczna i Środowiskowa”, 2, 18-24.

$\mathrm{P} l \mathrm{ag}$ e man n A., Harder T. (2005), Breast feeding and the risk of obesity and related metabolic diseases in the child, „Metabolic Syndrome and Related Disorders”, 3 (3), 222-232.

Russe 1 J. A., Douglas A. J., Ingram C. D. (2001), Brain preparation for maternity adaptive changes and neuroendocrine systems during pregnancy and lactation. An overview, „Progress in Brain Researches”, 133, 1-38.

S a vage J. S., F i s her J. O., B ri c h L. L. (2007), Parental influence on eating behaviour: conception to adolescence, ,Journal of Law Medicine \& Ethics”, 35, 22-34.

S avino F., Liguori S., Fis s ore M., Oggero R. (2009), Breast milk hormones and their protective effect on obesity, „International Journal of Pediatric Endocrinology”, $10.1155 / 2009 / 327505$.

S jogren B., Widstrom A. M., Edman G., Uvnas-Moberg K. (2000), Changes in personality pattern during the first pregnancy and lactation, ,Journal of Psychosomatic Obstetrics and Gynecology", 21, 31-38.

S p o k B., R o th e n berg M. B. (2000), Dziecko, PZWL, Warszawa.

$\mathrm{S}$ t u e b e A. (2009), The risk of not breastfeeding for mothers and infants, ,Review of Obstetrics Gynecology", 2 (4), 222-231.

T averas E. M., Scanlon K. S., B irch L., Rifas-Shiman S. L., R i ch-Edwards J. W., G i $11 \mathrm{~m}$ a n M. W. (2004), Association of breastfeeding with maternal control of infant feeding at age 1 year, „Pediatrics”, 114, e577-e583.

WHO Growth Reference 5-19 Years, (2007), World Health Organization, Department of Nutrition, Geneva, Switzerland.

\section{Breastfeeding in infancy, parenting practices in early adolescence and body mass of 13 year olds - analyses of relationships}

Objective: To analyze relationships between breastfeeding duration, mothers' parenting practices and body mass of thirteen years old.

Subjects and methods: Prospective cohort of newborns identified after hospital birth and followed-up at 3 years and at 13 years was analyzed. At 3 years the mothers' reports about breastfeeding were collected. Thirteen years old and their mothers filled up short version of 
Alabama Parenting Questionnaire. The group of 535 adolescents and their mothers was included in the analysis.

Results: Thirteen years old which as a young children were breastfed for a long time evaluated their mother's discipline and supervision in the most positive way. The risk of overweight for children brought up by mothers using inconsistent discipline was almost twice then for peers.

Conclusion: Breastfeeding influence on children's body mass can be mediated and improved by mother's parenting practices.

Keywords: adolescents, breastfeeding, parenting practices (nastolatki, karmienie piersią, funkcje rodzicielskie). 